\title{
ENSURING ECONOMIC SECURITY OF THE REGIONS: EUROPEAN EXPERIENCE AND UKRAINE
}

\author{
Rostyslav Bilyk \\ PhD in Economic \\ Yuriy Fedkovych Chernivtsi National University \\ 2 Kotsjubynskyi str., Chernivtsi, Ukraine, 58012 \\ r.bilyk@chnu.edu.ua
}

\begin{abstract}
The article justifies problems and perspectives of ensuring economic security of the regions. It proves that economic security of the region is implemented via its ability to counteract internal and external threats, for the purpose of ensuring implementation of economic interests of the region while effectively using competitive advantages. It also describes European experience, in particular, regarding institutional and legal groundwork, organizational, financial ensuring of economic security of the regions and interregional formations. It proves that cooperation between Ukraine and European institutions goes through the period of making important strategic decisions that should dramatically affect further strategic vector of economic and security development of Ukraine and help to find a position regarding establishment of efficient security system - economic, political and military.
\end{abstract}

Keywords: region, regional policy, economic security of the regions, institutional groundwork.

\section{Introduction}

The basis for ensuring economic security is represented by the degree of independence and ability of the region to establish its own economic policy with regard to its peculiarities, where the first stage is decentralization, allocation of administrative functions between centralized state power and regional administration. Decentralization (failed efforts of which are suggested by the amendments to the Constitution) gives an impetus to economic development of the regions, increase of competitive ability of economic entities, improvement of quality and living standards of the population in the regions.

Regardless of the initiated reforming of the state system for the regional development governance in Ukraine, implementing new approaches towards stimulation of territory development and modern mechanisms still remains mainly declarative, and relations on the level "center-region-territorial community" are being established under the strict control or are not being governed at all.

So, European experience as to the policy for strengthening economic security of the regions has an out and outer value.

Research of theoretical and methodological fundamentals and elaboration of methodological and practical suggestions as to ensuring economic security of the region in Ukraine with regard to the European experience.

\section{Review of main sources of research and publications}

Research of the problems for regional economic security was conducted by many scientists. Among the national scientists one should specify, in particular, who emphasize the problems of determining and mechanisms for ensuring economic security of the region [1]; study a number of key problems as to the optimal mechanism for ensuring economic security of the regions of Ukraine [2]; emphasize security of structural and institutional transformation of the economy in the region [3]. Some scientists, in particular, see the problem of establishing economic security of the region through the realization of its economic interests as a condition for ensuring regional development [4]. The process for strengthening economic security of the regions is studied in the context of the prospects for socioeconomic development of the regions [5]. The issue of economic security of the regions is considered from the standpoint of strengthening foreign economic security, international aggregate cooperation etc [6-8]. 
Regardless of the available research, initiated reforming of the state system for the regional development governance in Ukraine, sufficient attention is not being paid to strengthening of economic security of the regions, in particular, towards its legal and financial provisioning. Within this context research of the problems of ensuring economic security of the region in Ukraine with regard to the European experience does not become irrelevant.

\section{Purpose and objectives of the research}

The purpose of the work is to study theoretical and methodological fundamentals and to develop methodological and practical recommendations as to ensuring economic security of the region in Ukraine with regard to the European experience.

In order to reach the specified purpose the following objectives were specified:

1. To reveal the essence of the economic security of the region.

2. To determine peculiarities of international, in particular, European experience as to ensuring economic security of the region.

3. To analyze regional policy of Ukraine as to ensuring economic security of the region.

4. To suggest practical recommendations as to ensuring economic security of the region in Ukraine with regard to the European experience.

\section{Materials and methods of research}

Theoretical and methodological basis of the research is represented by fundamental factors and principles of the modern economic theory, theories of regionalism, institutionalism, global economy, and scientific works of national and foreign scientists on issues of ensuring economic security of the region. There was applied a system of methods and approaches that ensure conceptual integrity of the research - theoretical generalization, comparison, analysis and systematization (when studying the essence of economic security of the region, structural and factorial analysis (to define peculiarities of international, in particular, European experience as to ensuring economic security of the region)); methods of institutional analysis, establishment of cause-effect relations (when studying experience of implementing institutional changes in regional policy) etc. informational basis of the research is represented by normative and legislative acts, official documents of the European Union, official publications of statistic authorities and international organizations, scientific works of leading national and foreign scientists, Internet resources etc.

\section{Results of the research}

Problems and perspectives of ensuring economic security of the regions with regard to the European Union were defined. It was proved that economic security of the region is implemented through its ability to counteract internal and external threats for the purpose of ensuring implementation of economic interests of the region at effective usage of competitive advantages.

\section{Discussion of the results}

Intensification of the regional integration in modern conditions goes along with intensification of influence on the condition of economic security of the region of the outside environment, which is being characterized with the high level of organizational complexity, non-stability and uncertainties [9]. Strengthening of the economic security of the region-participant of international relations depends on the level of its adaptive capacity to external challenges and ability to apply maximum effectively possibilities and advantages of the international cooperation.

Economic security of the region is implemented through the change of states of economic system of the region, which characterize its ability to resist internal and external threats, for the purpose of ensuring realization of economic interests of the region with effective application of competitive advantages.

Change of bipolar global order into multipolar did not reduce amount of challenges against states, and only reformatted the system of their external relations and security. The problems of regional security in modern conditions include the issue of military and ethnical 
conflicts, political, economic and military interaction, creation and dissolution of interstate and international associations.

Security of subnational associations includes a set of elements of the national security, factors of regional system of international relations and spatiotemporal measures as to their implementation. Security of separate participants of megaregional system is basically regarded as a set of measures for removal of internal and external threats. Many European states, in particular so-called "new democracies", possess very limited own force resources to ensure security. To organize provisioning of their own security they objectively have to establish certain forms of coalitions, unions or regional associations. Thus, regional security is based on common efforts of the members of integration associations and has binary nature: on the one hand, it is a factor of stability and security of the region in general, and on the other hand a guarantee of security of each member in particular [10]. Regional security in modern conditions stipulates simultaneously a certain level of regional identification, which covers not only military or political aspects, but also cultural and mental peculiarities of cooperation and interaction between the participants of megaregional formations.

Having signed the European Union Association Agreement with the EU in June 2014, openness of the regions of Ukraine continues to increase, and their interaction with regional economic systems of the EU states continues to grow. Intensification of structural deformations on the regional level due to the global crisis 2008-2010 and armed and political conflict on the East of Ukraine in 2014-2015 along with the low adaptive ability of the regions of Ukraine to the threats of external environment causes a critical impact on the state of the national economic security. Competitive ability of the national regions through the mobilization of the internal potential along with the rational use of external resources - structural assistance of the EU, in particular, - on the basis of improving institutional fundamentals to a huge extent establishes effectiveness of implementing structural policy in Ukraine.

In the process of establishing joint market and political integration by the European Union a common mechanism for making decisions has been established within the trading, competitive, agrarian, regional, social, industrial and scientific and research policy, - an agreed one with regard to the criteria of economic security. Structural reforms, implemented in the EU for the purpose of removing regional, industrial and social disproportions (that existed due to imperfect sectoral, spatial and intuitional structure) first of all were aimed at reducing treats to the regional development. Reforms were successfully implemented owing to financial provisioning on behalf of the Structural funds [11] of such structural policy through the projects on modernizing and restructuring economics.

Effectiveness of protecting interests within the megaregional or interregional association depends on the ability of the regions-participants to resist jointly to internal and external threats, economic and institutional contradictions in relationships "international associations - state", "state - state", "region - region", "state - region". Economic security of subnational level depends on the level of consent of interests of all participants, compliance of their interests with the interests of each participant separately and overall aims in general [12].

Even though over the recent years Ukraine has gained a real possibility to participate in interregional and other international associations, which could provide the possibility of strengthening economic security both of the state and regions, but due to poor quality of the strategies for regional development and their misalignment with strategic documents, approved on the national level, cause low activity of the regions in the international security environment. Application of program and purposeful approach will allow increasing effectiveness of implementing strategic tasks of the regional development.

Developing strategy for a state or regional participation in interregional security cooperation one should accord it with the basic program documents of international, national and regional level. Such strategy should become a basis for developing mid-term and short-term programs for economic and social development of a separate region-participant of the association. 
Joining to the international subnational association bear a range of threats and challenges in itself, the means for reducing of which are advantages from participation in such associations, in particular:

- creating favorable investment climate based on the differentiated approach to specification of investment conditions;

- strengthening competitive advantages of the region-participant through implementation of international projects, investment in particular;

- improving information support through informing public on results of implementing joint projects, creating regional basis of international projects;

- developing innovative and financial infrastructure;

- increasing effectiveness of activity of state institutions and local authorities due to expansion of powers of local authorities in the field of international cooperation [7].

Considering international experience, studied materials and research results, a strategic document of the regional or state participation in megaregional association for the purpose of strengthening economic security should include the following key provisions, as shown in Table $\mathbf{1 .}$

Table 1

Key provisions of the strategic document of the regional or state participation in megaregional association

Provision Meaning

Justifying economic and institutional preconditions for development of international cooperation

Analyzing institutional and legal basis

Measuring level of economic security

Defining internal and external risks and threats

Specifying competitive advantages of the regions-participants

Development prospects of international regional cooperation

Instruments, methods and ways
On the basis of studying European regional policy for regional cooperation

Ensuring international cooperation of the regions and analyzing cooperation trends of the regions in foreign trade, investment and scientific fields

The most susceptible figures to the effects of international cooperation (investment, foreign economic, scientific, and production types of security)

Level of their impact on economic security of the regions

Priority areas of implementing joint projects

Influence on the state of socioeconomic development and level of economic security of the regions-participants

Optimization of management system of economic security of the subnational association in the process of international cooperation

Currently integration processes became an objective reality. It was resulted in creation of many regional and subregional blocks, choosing stage of economic cooperation and security as their targets. Nowadays there are about 20 largest international economic associations of integration kind, which have covered major regions and continents of the globe.

The basis of the integration - direct international economic (production, scientific and technical, technological and others) relations on the level of primary economic entities, which in their development ensure gradual binding of national economic entities. Results of the regional integration are manifested in synchronization of socioeconomic development processes of the countries, approximation of national macroeconomic figures, intensification of interde- 
pendency of economies, growth of the GDP and labor productivity; growth of production scale, creation of regional markets.

The largest integration association of the Europe (which Ukraine is going to enter into) and simultaneously the largest economy of the globe currently are represented by the European Union (28 member-states). It has its own currency and growth prospects, which are defined not only by the economy growth of the European Union states, but also by membership of new states. In general, in 2014 GDP of 19 states of the European area grew up by $0.9 \%$ and within 28 states of the European Union - by $1.4 \%$. According to the IMF, in 2014 GDP of the EU made up 14303 billion Euro (18 451 billion US Dollars) [13] (Fig. 1). Main declared targets of the renewed EU are to establish political union based on introduction of the European citizenship; to ensure freedom, security and legitimacy; to contribute to economic and social progress; to strengthen European role all over the globe.

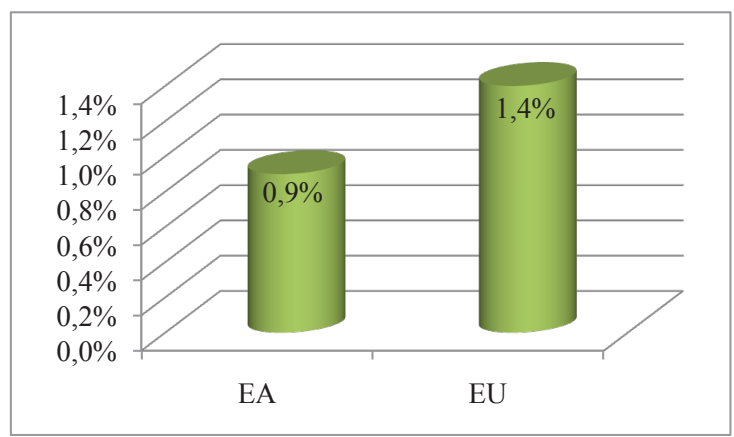

Fig. 1. GDP growth of the European area and the European Union in 2014, \%

Ukraine participates and carries out foreign political and economic activity in the following subregional structures:

1. The Visegrad Group.

2. The Central European Initiative.

3. Organization of the Black Sea Economic Cooperation and Parliamentary Assembly of the Organization of the Black Sea Economic Cooperation.

4. Baltic cooperation.

5. The project "European region".

6. The GUAM.

7. Organization for Democracy and Economic Development.

8. Bilateral and multilateral mechanisms of cooperation:

- Ukraine - Poland - Romania;

- Ukraine - Moldavia - Romania;

- Ukraine - Poland - FRG;

- Ukraine - Poland - Lithuania and others.

In general, emergence of regions in up-to-date understanding them as an institutional unit is pretty new for Europe and has been developing since 1970s, when the European Union initiated a regional policy for supporting obsolete and restructuring old industrial regions, which actually turned to be a driver for regionalization. New for them regional structures emerged in a number of European states - in Greece, Portugal, Ireland, and Finland in particular. Understanding of regional policy for diverse states was different and initially establishment of the regions had only characteristics of administrative regionalization, which later was experienced by the states of the Central-Eastern Europe in the process of their joining the EU. A key characteristic for developing policy for regionalization during this period was a loss of monopoly for ensuring regional development by the states. Out of a governing structure a state turned into a partner of local authorities, public associations and economic entities.

Such change in planning of the regional development, where a leading role belong to the local authorities and considerable share of functions was shifted from the center to the provinces, required establishment of the institutions for ensuring coordination of the regional policy and financial support for problem territories. Thus, for the purpose of financing the least developed regions the 
EU created the European Regional Development Fund that became a first stage for elaborating policy for economic security of the region. The next one to establish was a European Social Fund responsible for governing the policy for reducing unemployment in the regions with low development level, and European Fund for Governing and Ensuring Rural Households. A wave of joining EU by new member-states showed imperfectness of the regional policy, when with adjunction of new member-states to a regional community a level of differentiation between the regions increased in several times. It became obvious that integration is not an automatic resolution for socioeconomic problems of the states that became its members. It caused revision and improvement of the regional policy of the EU.

The next step for improving regional policy was to establish the Committee of the Regions based on the Maastricht treaty, results of which, however, were not as positive as expected: major share of the governments of the states did not wish to provide regions with specific authorities and power, as they had in their states sufficient amount of bodies and institutions, responsible for regional policy. Practically, a half of the members of the Committee were representatives of local authorities. Efforts to elaborate common understanding of the region as a certain independent institution were unsuccessful also in terms of the very interpretation of the region in program documents - as an economic area for policies of regional development for the purpose of official government support and removal of disproportions in regional development within "the limits of the policy for economic and social uniting (cohesion)" [12].

Regardless of the improvement of the institutional component of the regional policy at the beginning of the XX century unresolved remained the issues of financing, resolving regional problems and sparseness of allocated funds among large number of objectives and regional initiatives. And beginning of the XIX century posed to the European Union a task to change financial component of the regional policy. Adoption in 2000 of the document "Agenda 2000" was aimed at considering existing problems and focusing on new development directions, which included: effective application of subsidiarity principle, which over the all those years remained one of key ones; strengthening of concentration of financial aid by means of reducing number of initiatives and objectives, for which funds were allocated; expanding are of financial influence to the regions of candidates-states to enter EU.

The most positive changes in economic policy of the EU affected states of the former socialistic area, which gave them a possibility to level up negative consequences of collapse of socialistic system and to improve the level of socioeconomic development of their own regions.

One of the greatest advantages of a new European policy for the regional development was an essential increase of institutional and financial support for development of knowledge-intensive industries - about $70 \%$ of funds, allocated by the Structural funds, were aimed at financing scientific \& research and innovative activity, development of human capital, basic infrastructure and development of information society. However, regardless of introduced changes, a number of problem aspects of unsteady regional development still remained, when in Luxemburg, in particular GRP per one citizen made up $253 \%$ of the average figure over the EU, and in regions of Romania instead $-28.3 \%$, which is eight times less [14] (Fig. 2). Problem aspects of the regional development of the EU from the beginning of the XIX century were differentiation of the regions in terms of GDP, salary, level of unemployment etc.

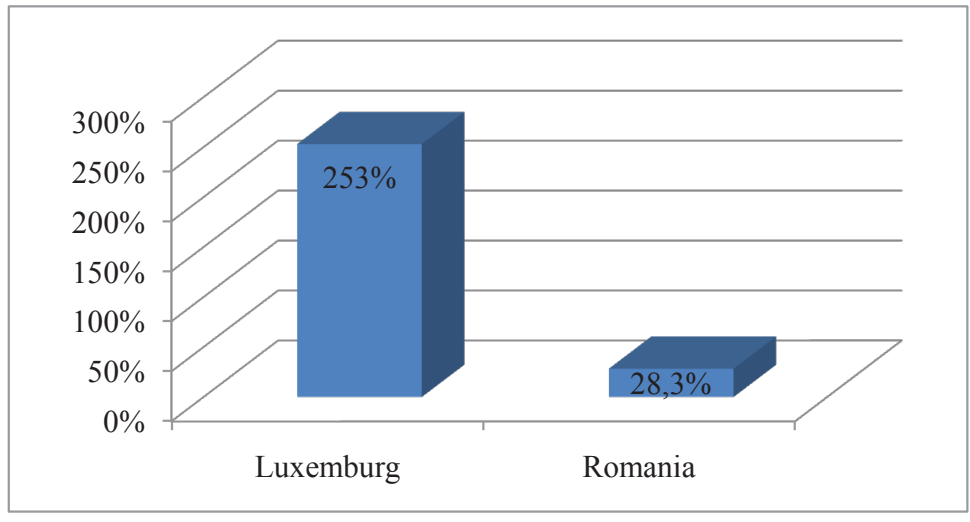

Fig. 2. GRP per one citizen of the average figure over the EU, $\%$ 
Specified problems resulted in active population migration from depressive regions of the Central-Eastern Europe states to the regions of highly developed EU states, which caused reformation of the regional policy of the EU in 2007-2013. Main principles of the reforms became:

1) implementation of the policy for uniting (cohesion) all member-states of the EU with huge level of financing;

2) concentration of activity only in terms of convergence of the regions, European territorial cooperation and regional competitive ability and employment;

3) reduction of number of structural elements of financial and economic policy.

Change of directions of regional policy resulted in strengthening of understanding of a necessity to develop interregional cooperation, in particular, on the international level, which became an important factor for rapprochement of the regions and increase of their competitive ability, which was evidenced by increase of a share of financing for innovative projects and scientific research that surpassed in three times financing of this area during the previous years. Analyzing conducted reforms and directions of regional policy improvements, one should specify the following factors of effective implementation of the reformed economic policy:

- transparent mechanisms and instruments of adjusting, harmonizing relationships "center-capital city of the country-regions";

- highly effective model for convergence of the regions, introduced by the EU;

- long-lasting and inviolable subsidiarity principle;

- applying state special-purpose programs;

- establishing regional budget funds and special authorities, responsible for implementation of the regional policy;

- complying with the principle of solidarity, which ensures rendering of assistance to the least developed regions by the most developed ones;

- transferring considerable share of powers from the center to local places, decentralization of finances and expansion of spheres of influence of local authorities.

Specified preconditions and forms of development of the institutional ensuring of implementation of the regional development policy for the EU states give basis to state that its large-scale governing on the supranational, national and regional level. Increase of the level of socioeconomic development of the European regions, considerable decrease of the level of regional differentiation occurred owing to the implementation of the effective model for governing regional development, main task of which is to mobilize external and internal resources and their optimal allocation on the basis of private-state cooperation and regional programming. An important element of such positive model is represented by the local authorities, which participate in development of mechanisms for coordination of regional programs within the state, implement programs for regional development and create local partnerships. Development, coordination and implementation of regional EU programs create preconditions for establishing interregional cooperation based on the regional partnership.

Conducted research of integration processes and regionalization gives fundamentals to make conclusions that accelerated development of the national economies and global economy is followed by emergence of numerous integration regional groups, which open prospects and new possibilities of rapprochement and joining national economies, participation in international economic cooperation, conditioned by combination of economic space, creation of more stable and predictable situation for development of mutual trade, trans-border capital and labor force flow, use of advantages from the scale effect, creation of favorable external political and internal economic environment. New prospects and new possibilities engaged into the integration processes more and more sovereign states. A state that is not a member to any available regional (subregional) integration unions is expected to become an outsider, counteracting united economic and political force of several states.

Integration as a complicated and contradictory process to a large extent is based on the differences of the parties happens easily enough in the field of market (goods) turnover, and in a more complicated way in production field, and in the most complicated way - in currency field. Large-scale integration cooperation in the EU sates leads to intensification of the international 
competitive ability, increase of specialization and diversification of production, ensuring technological cooperation, reduction of production and transaction expenditures. Liquidation of tariff barriers contributes to enlargement of the markets, integration aggravates competition and pushes out non-effective producers, positively affecting investment climate, contributes to capital inflow into the state.

Global experience of establishing and developing regional and subregional integration associations confirms possibilities of interstate integration in various forms, which differ substantively in terms of a number of states that are being integrated, level of mergence of national economies, depth, field and scalability of the processes, objectives of cooperation, independency and nature of relationship between the member-states.

Regardless of existing differences, a motivator for creating regional integration unions is an effort to gain benefits in the area of economic and technological cooperation and international trade with intensification of inter-economy relations, possibility to transfer individual interests of a separate region or state to the group ones for the purpose of successful expansion to the global markets. Participation of Ukraine in regional associations for protection of security and contributing to economic growth should be conducted on mutually beneficial fundamentals with regard to the needs and interest of domestic regions, industries and enterprises.

Protection of own interests and interaction with the EU and European structures nowadays are under the threat considering the period of armed conflict on the East of Ukraine. With arrival of relatively quiet conditions on the Eastern border the European Union should make a decision as to its future program of the Eastern partnership - policy towards Ukraine, Moldavia, Belarus, Georgia, Armenia, and Azerbaijan. The issues of the Eastern partnership passed into the category of the largest geopolitical crises of the EU, faced by the Europe from the period of the Cold War.

Institutions responsible for the development and security program in the EU consider reforming plans of the Eastern partnership according to the changed circumstances, where each of the states-Eastern partners moves in a different direction (Ukraine, Georgia, and Moldavia - towards the EU, Azerbaijan moves separately, Armenia and Belarus - towards Russia) [15]. Respectively, the time has come for a more diversified approach in implementation of the policy of the Eastern partnership, by type "3-1-2" considering different aspirations and expectations from the relationships with the EU.

Events in the field of the institutional and legal groundwork for the development of the regions of Ukraine over the recent years (2014-2015), as well as changes in the regional policy in general require substantial analysis in the process of integration of the policy for the regional development into the general strategy for the state modernization.

The policy for regional development in Ukraine is being developed on the basis of the aggregate normative and legal provisioning, which covers over 20 Laws of Ukraine, Decisions of the Constitutional Court, Decrees of the President, Decisions of the Cabinet of Ministers of Ukraine and acts of the central executive authorities. Legislation of Ukraine on the issues of ensuring regional security rests on the legislation in the field of the state regional policy, the basis of which is the Constitution of Ukraine [16]. It also covers the Laws of Ukraine on Stimulation of the Regional Development, On Local Self-Administration in Ukraine, On Local State Administrations, On Trans-Border Cooperation, On Government of Urban Planning Activity, On State Special-Purpose Programs, On State Forecasting and Developing Programs for Economic and Social Development of Ukraine, On General Planning Scheme of the Territory of Ukraine and others.

Among the subjects of the policy for ensuring economic security on the regional level legislation of Ukraine specifies only territories of the regions, as well as of the groups of the regions, united according to the specified criteria, but the legislation lacks a notion of protection of rights of the territory community, which is a "primary subject of local self-administration, main carrier of its functions and powers is a territory community of a village, settlement, city" (The Law of Ukraine On Local Self-Administration [17]). On the one part, territory communities are the subject of ensuring policy for economic security, and on the other - it is their interest and rights that must be protected by the policy for region security [18].

Considering sociopolitical transformations, suffered by Ukraine in 2014-2015, it is necessary to lead modernization of the regional development. The State Strategy of the Regional De- 
velopment up to 2020 regarding this issue specifies: "starting from 2014 there occurred additional risks related both to external influence of the Russian Federation acts towards the Autonomous Republic of Crimea, Sevastopol city and Eastern regions of Ukraine, and internal factors, caused by insufficient state policy" [19].

For Ukraine, in addition to resolution of the conflicts and maintenance of the Russian sanctions, structures of the European Union emphasize the necessity for the larger short-term financial support in order to help against debt trap. Ukraine faces with a complicated task to gain to the full extent benefit from the DCFTA, which should be implemented in 2016 regardless of that a large share of the industrial potential in Ukraine has been destroyed, there are persuasive arguments in favor of the greater financing by the EU to lead required economic transformations. Peculiarly for the EU economic support for Ukraine is a huge challenge as far as after failed attempts of reforming after the Orange Revolution in 2004 defeat in assistance with implementation of deep reforms this time will significantly damage authority of the EU all over the globe.

\section{Conclusions}

As a result of conducted research:

1. The essence of economic security of the region was disclosed; problems and perspectives of ensuring economic security of the regions were defined. It was proved that economic security of the region is implemented through its ability to counteract internal and external threats.

2. Peculiarities of international, in particular, European experience as to ensuring economic security of the region were defined. It was proved that cooperation between Ukraine and European institutions passes through the period of accepting important strategic decisions, which should significantly affect the following strategic vector of economy and security development of Ukraine and provide assistance in occupying a position as to establishing effective security system.

3. Situation and problems of implementing regional policy of Ukraine as to ensuring economic security of the region were analyzed.

4. Practical recommendations, in particular, as to institutional and legal, institutional and economic ensuring of the economic security of the region in Ukraine with regard to the European experience were suggested.

Based on the analysis of the international experience, in particular, European, regarding developing policy for regional security and necessity for strengthening participation in interregional associations, it is required to develop a strategic document on the region participation in such interregional association for the purpose of strengthening economic security. Key fundamentals of which should become (1) analyzing institutional and legal basis for ensuring international cooperation of the regions and analysis of the trends of cooperation among the regions in foreign trade, investment, scientific and technical fields, (2) measuring the level of economic security of the most vulnerable to the effects of the international cooperation figures (investment, foreign economic, scientific and technological, production security) and defining the level of influence of threats on economic security of the regions, (3) prospects of development of international regional cooperation and its influence on the level of economic security of the regions-participants; (4) defining mechanisms of managing system of economic security of the subnational formation in the process of international cooperation. On the current stage of the development of Ukraine international interregional cooperation is a necessary element for strengthening security of the regions.

Within the context of improving policy for ensuring regional security, with regard to importance of the territory communities' role, priority directions of reforming should become: optimizing territory basis of public power with allocation of area of powers of local executive authorities and local self-administration authorities; improving quality of life of residents of the regions, decreasing differentiation in terms of the Human Development Index, creating polycentric system for territory development; implementing interregional projects and programs for effective use of local resources; introducing criteria of assessment of "problem: territories in the regions, effective mechanisms of state support for interregional integration.

Introduction of the specified measures in the system of institutional and legal groundwork and organization and economic provisioning of the economic security of the region will first of all 
raise legal consciousness and public activity of the representatives of territory communities. As far as they constitute basis of the economic system of the region and its socioeconomic development, ensuring economic security on the level of territory communities will provide a possibility not only to improve system for government of regional development, but also to raise the level of protection of economic interests of the state.

Ukraine is the largest strategic challenge for economic and security policy for the EU. Currently European Community should make a complicated decision on further fate of the European integration process of Ukraine, simultaneously understanding that huge price, which the state pays for its "European choice". Cooperation of Ukraine and European institutions passes the period of making important strategic decisions, which should dramatically affect further strategic vector of development of economy and security of this state and decide on creation of effective security system - economic, political, and military.

\section{References}

[1] Herasymchuk, Z., Vavdiiuk, N. (2006). Economic security of the region: diagnostics and mechanism for ensuring. Lutsk: Nadstyria, 244.

[2] Holovchenko, O. (2008). Economic safety of the region in the process of guaranteeing stability of the national economy. Odesa: Publisher Bukaiev Vadym Viktorovych, 399.

[3] Humeniuk, A. (2014). Security of structural and institutional transformation of the region: theoretical fundamentals and applied aspects. Kyiv, 468.

[4] Bohdan, N., Kosiak, A. (2013). Establishment of economic security of the region through the implementation of its economic interests as a condition for ensuring regional development. Economy and a region, 1, 2631.

[5] Sukhorukov, A., Kharazishvili, Yu. (2012). Modeling and forecasting of socioeconomic development of the regions of Ukraine: a mon. Kyiv: NSID, 368.

[6] Babets, I. (2011). External economic security of the regions of Ukraine under conditions of cooperation with the EU countries: theoretical and methodological and applied aspects. Lviv: PAIS, 400.

[7] Babets, I. (2013). Conceptual fundamentals of the strategy of economic security of interregional cooperation of Ukraine with the EU states. Scientific bulletin of the Lviv State University of Internal Affairs. Economic series, 1, 3-13.

[8] Yaremko, L. (2007). Globalized region and foreign economic security of Ukraine: theoretical and methodological aspect: a. Lviv: Publishing of LKA, 524.

[9] Babets, I. (2013). Methodology for establishing economic security of the interregional cooperation of Ukraine with the EU states. Strategic directions of development of the national economy during a post-crisis period. Lviv: Spolom, 272.

[10] Starodub, T. (2001). Processes of creating regional identity of Ukraine as a factor of its foreign policy in the field of security. Kyiv, 22. Available at: http://avtoreferat.net/content/view/7873/23/

[11] Fundusze strukturalne. Available at: http://www.fundusze-strukturalne.pl/

[12] Varnalii, Z. (2005). Regions of Ukraine: problems and priorities of socioeconomic development: a monograph. Kyiv: Knowledge of Ukraine, 498.

[13] International Monetary Fund. Available at: http://www.imf.org/data

[14] Regional Gross Domestic Product (PPS per inhabitant). Available at: http://ec.europa.eu/eurostat/web/products-datasets/-/tgs00005

[15] Hug, A. (2015). A difficult future for the EU's Eastern Partnership. Available at: http://esharp. eu/debates/external-action/a-difficult-future-for-the-eus-eastern-partnership

[16] Bilyk, R. (2014). Tasks for improving institutional and legal groundwork of the regional policy of Ukraine. Bulletin of Vinnytsia National Technical University, 4, 40-45.

[17] The Law of Ukraine On Local Self-Government. Available at: http://zakon4.rada.gov.ua/laws/ show $/ 280 / 97-\%$ D0\%B2\%D1\%80

[18] Bilyk, R. (2015). Organization and economic mechanisms for ensuring economic security on the regional level. Economics and Finances, 5, 16-25.

[19] “On Approval of the State Strategy for Regional Development for the period until 2020". Decree of the Cabinet of Ministers of Ukraine Available at: http://zakon1.rada.gov.ua/laws/show/385-2014-\%D0\%BF 